\title{
The Preparedness of Emergency Medical Services Students for Coronavirus Disease 2019: A Cross- Sectional Study among Paramedic Students
}

\author{
D. M. AL RAZEENI, A. AL-WATHINANI, R. ALHAZMI , O. A. SAMARKANDI ${ }^{1}$, S. A. RONAL ${ }^{2}$, BASMA SALAMEH ${ }^{3}$ AND A. \\ ALENAZI ${ }^{4 *}$
}

Department of Emergency Medical Services, ${ }^{1}$ Department of Basic Science, Prince Sultan bin Abdulaziz College for Emergency Medical Services, King Saud University, Riyadh 11466, Saudi Arabia, ${ }^{2}$ School of Health Sciences (STIKes) Kepanjen Malang, Kabupaten Malang 65163, Indonesia, ${ }^{3}$ Department of Nursing, Arab American University, Jenin, Palestine, ${ }^{4}$ Pharmacy Department, Prince Sultan Cardiac Center, Riyadh 12233, Saudi Arabia

Al Razeeni et al.: Preparedness of Emergency Medical Services Students for Coronavirus Disease 2019

\begin{abstract}
Emergency medical services providers, including emergency medical services students are among healthcare professionals on the front line to fight coronavirus disease 2019 and are under a greater risk of exposure. Preparing emergency medical services students to safely provide healthcare during the pandemic is vital. Therefore, this study assesses the emergency medical services student's preparedness for coronavirus disease 2019 in Saudi Arabia. A descriptive cross-sectional survey was conducted. This study was conducted at Prince Sultan Bin Abdulaziz College for Emergency Medical Services in King Saud University in Riyadh, Saudi Arabia. In this study, 198 students participated. The emergency medical services students thought they are insufficiently prepared to face situations, such coronavirus disease 2019 (2.50 \pm 1.57$)$. Regarding knowledge, the emergency medical services students thought that they are insufficiently prepared for coronavirus disease 2019. The emergency medical services students thought that they are insufficiently contributing to local or national-level efforts associated with coronavirus disease 2019 (2.40 \pm 1.34$)$. Among the emergency medical services students, $83 \%(n=132)$ presented a feeling that they were not satisfactorily equipped to counter coronavirus disease 2019 situation. Furthermore, $87 \%(n=138)$ of the emergency medical services students thought that embedding coronavirus disease 2019 related topics in the emergency medical services curriculum and theory and practical training would help prepare them. The emergency medical services students have moderately inadequate knowledge and skills related to coronavirus disease 2019. Moreover, they indicated that they are uncertain about their ability to respond adequately to, or participate satisfactorily in, pandemic-related events. The emergency medical services students have expressed the need for more knowledge and skills related to coronavirus disease 2019 to be embedded in the emergency medical services program curriculum.
\end{abstract}

Key words: Preparedness, emergency medical services, emergency medical services students, coronavirus

The coronavirus disease 2019 (COVID-19) is caused by a novel human coronavirus (severe acute respiratory syndrome coronavirus 2 (SARS-CoV-2)), classified as 201-nCov, which appeared at the end of 2019 and has spread worldwide, causing a pandemic ${ }^{[1]}$. In December 2019, patients with COVID-19 in Wuhan City, China were recognized to be infected ${ }^{[2-4]}$. They presented with signs and symptoms of viral pneumonia ${ }^{[5]}$. Common human coronaviruses typically cause mild symptoms, such as cough or cold, but SARS-CoV-2 has led to more severe respiratory illnesses and deaths worldwide ${ }^{[6]}$.

COVID-19 can spread between humans by respiration of an infected individual's aerosols ${ }^{[2]}$. Elderly patients with chronic diseases, such as hypertension, heart disease, lung disease, cancer and diabetes were recognized to be at a higher potential risk of serious illness and mortality ${ }^{[7,8]}$. World Health Organization (WHO) urges

*Address for correspondence

E-mail: dalrazeeni@KSU.EDU.SA 
the prevention of human-to-human transmission by preventing/limiting close contacts ${ }^{[9]}$. The most effective prevention strategies include frequent hand washing, social distancing and respiratory hygiene ${ }^{[8,10]}$.

As of February 2021, almost 112 million were COVID-19 positive. Approximately 87 million people had recovered from the disease, whereas almost 2.5 million individuals died ${ }^{[11]}$. With all efforts made worldwide, from a report by the WHO, the number of cases is still increasing in several countries. The significant efforts rendered by the government of Saudi Arabia hold a gradual increase in cases with a total number of cases of 375333 total recoveries of 366412 and total mortality of $6466^{[11,12]}$.

Currently, several COVID-19 vaccines have been approved and are being used worldwide. Several drugs have been approved for public use ${ }^{[13]}$. Immunization programs have started in many countries, prioritizing health workers, elderly individuals and those at the most risk ${ }^{[6]}$. The pandemic is critical for health workers with a frightening work demand, persistent conversion of information and concerns of self-protection during the care of patients ${ }^{[14]}$. Emergency Medical Services (EMS) providers including EMS students are among the healthcare professionals who are facing directly COVID-19 pandemic and are under a greater risk of exposure to various hazards, such as pathogens, long and difficult working hours, psychological effects, fatigue and job burnout ${ }^{[15]}$. Lacking the knowledge of such dangerous disease may harm EMS students and could lead to failure in patient assessment and treatment, causing the rapid spread of the virus. Therefore, preparing EMS students to safely provide patient care during the pandemic is vital.

Few studies have focused on preparing EMS workers to successfully and safely face epidemics and pandemics including COVID-19. A study in China involving Health Care Workers (HCWs) has found that $89 \%$ of them showed sufficient knowledge about COVID-19 and $89.7 \%$ follow the right protocols for self-protection against COVID-19 transmission. Doctors showed a higher understanding level $(38.56 \pm 3.31)$ than nurses (37.85 \pm 2.63$)$ and EMS paramedics (36.72 \pm 4.82$)$ ${ }^{[16]}$. Similarly, in a descriptive study, Saqlain et al. ${ }^{[17]}$ have identified obstacles that HCWs face regarding COVID-19. The study has revealed that HCWs have satisfactory knowledge (93.2\%), attitude (mean $8.43)$ and practice $(88.7 \%)$ regarding COVID-19 and pharmacists had greater knowledge $(94.7 \%)$ than physicians (93.3 \%) and EMS paramedics (90.5\%) and no significant differences in the variance were found $(\mathrm{p}=0.383)$. In the EMS setting, Alrazeeni et al. has reported that only $4.2 \%$ of EMS students have adequate information on the transmission, diagnosis and prevention of COVID-19 ${ }^{[18]}$.

A notable influence of COVID-19 on students of health programs was reported ${ }^{[19]}$. Healthcare students during their clinical practice might be considered a vulnerable populace and are likely to develop symptoms. The negative effects on student's mental health are among the consequences of the pandemic ${ }^{[20]}$. In healthcare facilities, managing patients with COVID-19 may shift the attention away from student's needs ${ }^{[21]}$.

In a recent report, EMS students encounter emotional challenges that have a possible adverse effect on the quality of patient care, their professional and personal life $^{[22]}$. It was emphasized that more instructional and educational obligations should be performed before, during and after EMS practical clinical training by educators of paramedical programs to reduce the impact of possible emotional challenges on EMS students ${ }^{[22]}$. This needs to be the focus of EMS educators and organizers to reduce these consequences. Initiatives that include the preparedness of healthcare students should come before and during pandemics ${ }^{[23,24]}$. Including pandemic content in the curriculum of health programs is essential to prepare students for any implication associated with the pandemic. Pandemic preparedness can involve embedding pandemic preparedness competencies, logistical challenges, leadership skills, problem-based learning and preparedness exercises in the curriculum objectives, learning outcomes and learning domains ${ }^{[25]}$.

\section{SIGNIFICANCE OF THE STUDY}

Saudi public, including HCWs and particularly EMS students have been affected by a certain degree of anxiety because of COVID-19. The Saudi government manages public anxiety using directives and initiatives and implemented roles and regulations ${ }^{[26]}$. Although Saudi Arabia was exposed to a small-scale coronavirus threat in 2015, at that time, hospitals, medical centres and other front line health services, including EMS were mobilized. That was part of the national pandemic plan. However, in spite of that, no study has explored the preparedness of EMS students for coronavirus spread. Therefore, this study was conducted to assess the preparedness of EMS students for COVID-19 in Saudi Arabia. 
This study was conducted to clarify the following three domains which includes EMS student's knowledge about COVID-19, EMS student's skills for COVID-19, EMS student's perception toward preparedness for COVID-19.

\section{STUDY ASSUMPTIONS}

This study was conducted to find answers to some questions and linkage to some assumptions about EMS student's preparedness relative to knowledge, communication venues, skills and contributions in the local or national effort for COVID-19 situations. Moreover, pieces of information regarding EMS student's preparedness in their educational program were investigated as follows: How do EMS students see their preparedness for COVID-19 during the EMS program? How did EMS students feel about the clinical and field practice during the COVID-19 pandemic? What are the areas that EMS students think they need more knowledge and skills in the preparedness? What would they suggest making the EMS program more effective in their preparedness?

\section{MATERIALS AND METHODS}

\section{Design:}

This study adopted a descriptive cross-sectional survey research design to investigate from the EMS student's point of view about their preparedness for COVID-19 during the EMS bachelor's degree program.

\section{Sample and setting:}

This study was conducted at Prince Sultan Bin Abdulaziz College for Emergency Medical Services (PSCEMS) in King Saud University in Riyadh, Saudi Arabia. In the semester when this study was conducted, the active number of students in the college was 198, who were chosen to participate.

\section{Instrument:}

A permission was obtained (in March 14, 2021) from the author to modify and use the Arabic version of the Disaster Preparedness Evaluation Tool (DPET) to gather data ${ }^{[27]}$. The research tool consisted of 36 items (20 on knowledge and 15 on skills) were marked using a 6-point Likert-type scale, ranging from strongly disagree to strongly agree. The rest of the items were the demographic information of the participants. Originally, "the questionnaires had high Cronbach's alphas of 0.910.93 , which measure internal consistency"[27].

\section{Procedure:}

Data were collected using self-reported questionnaires using an anonymous online survey link sent via communication channels to PSCEMS students in May 2021. A convenience sampling technique was used for recruiting EMS students during the outbreak of COVID-19 to maximize the response rate. For the overall safety, the transmission of hard copies between individuals was avoided. Therefore, the researchers decided to use WhatsApp Messenger for enrolling potential participants. The researchers identified all existing EMS students in the WhatsApp groups in the college. An online data collection tool was developed and implemented using Google Forms (through docs. google.com/forms). The Google Forms link of the questionnaire was sent over the specified WhatsApp groups.

\section{Data analysis:}

Descriptive analysis to determine the mean (M) and standard deviation (SD) was performed for the 52 modified DPET items. The variance in knowledge and skills related to COVID-19 among EMS students in the three student groups were measured using three MannWhitney post-hoc tests for each subscale. Statistical Package for the Social Sciences (SPSS) version 23 was used for all statistical analyses.

\section{Ethical consideration:}

Completed applications for Institutional Review Board (IRB) at King Saud University were prepared and submitted. Subsequently, the IRB approval decision (No. E-21-5896) was obtained in a formal letter. Before, during and after the data collection process, the researchers ensured the anonymity and confidentiality of the respondents by securing and saving the soft and hard copy information correctly. Furthermore, the researchers ensured that no risk is involved with the student's participation, answered the student's questions and request regarding the research data collection tools, having them click on the agreement of informed consent prior to the start of the survey and made the data available upon request.

\section{RESULTS AND DISCUSSION}

This study was conducted to evaluate the preparedness of EMS students for COVID-19. Of the modified DPET questionnaires distributed via an online link to 198 EMS students, 159 were completed and returned, with a response rate of $79.5 \%$. Demographic outcomes revealed that the student's age varied from 19 to $25 \mathrm{y}$ 
$(22 \pm 1.43 \mathrm{y})$ and all were male students. 53 students (34 $\%)$ were in $3^{\text {rd }} y$ and 55 students $(36 \%)$ were in $4^{\text {th }} y$, whereas 48 students $(30 \%)$ were in the $5^{\text {th }}$ and final year (internship-year students). 32 (20.5\%) students participated in managing real COVID-19 cases and/ or calls. 67 (42\%) students participated in COVID-19 related drills and activities (exercise, training course, workshops, etc.).

EMS students observation for their preparedness for COVID-19 was measured overall and DPET questionnaires ${ }^{[27]}$ were used to determine their knowledge and skills. The mean and SD of the responses gathered have been used ${ }^{[27]}$ to characterize the EMS student's perception as follows: 1-2.99=weak; 3-4.99=moderate and 5-6=strong. For the first research domain, "EMS student's knowledge about COVID-19," the EMS students thought they are insufficiently prepared to face

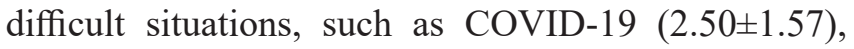
along with a general feeling of lack of communication venues where they practice. In other areas, the EMS students thought they are insufficiently prepared for COVID-19. The mean ranged from $2.50 \pm 1.57$ to $3.40 \pm 1.30$ (Table 1).

For the second research domain, "EMS student's skills for COVID-19," the EMS students thought that they are insufficiently contributing to local or national efforts related to COVID-19 (2.40 \pm 1.34$)$. The highest mean related to skills was $3.88 \pm 1.44$, whereas the lowest was $2.42 \pm 1.35$ ) (Table 2; items 2 and 8). Students requested further information when they were asked about certain areas of education related to their role in COVID-19; risks and resources in their communities; viral, bacterial, or pathogenic diseases and signs, symptoms, diagnosis and treatments of COVID-19 (fig. 1). As a response to the question on what would make them better prepared for COVID-19, $87 \%(n=138)$ of the EMS students thought that embedding COVID-19 related topics in the EMS program curriculum and introducing related practical training are helpful. Most EMS students $(83 \%, \mathrm{n}=132)$ specified that they were insufficiently prepared to respond to COVID-19 related events. Only $22 \%(n=35)$ participated in managing real COVID-19 cases, which included ambulance responses. Knowledge and skills related to COVID-19 varied among EMS students in the three student groups $\left(3^{\text {rd }} \mathrm{y}, 4^{\text {th }} \mathrm{y}\right.$ and $\left.5^{\text {th }} \mathrm{y}\right)$ according to the results of the three Mann-Whitney post-hoc tests for each subscale. The mean count of knowledge and skills total scores between groups was significantly different $\left(3^{\text {rd }} \mathrm{y}\right.$ and $4^{\text {th }}$ y students in knowledge: $U=65000, z=-7.238, p \leq 0.001$ and in skills: $U=53000, z=-7.340, p \leq 0.001 ; 3^{\text {rd }} y$ and $5^{\text {th }}$ y students in knowledge; $U=62000, z=-7.213, p \leq 0.001$ and in skills; $U=55000, z=7.499, p \leq 0.001$; and $4^{\text {th }} y$ and $5^{\text {th }}$ y students in knowledge: $\mathrm{U}=252000, \mathrm{z}=-4.862$, $\mathrm{p} \leq 0.001$ and in skills: $U=196000, \mathrm{z}=-5.527, \mathrm{p} \leq 0.001$ ). Senior students $\left(5^{\text {th }} \mathrm{y}\right)$ had higher average scores than junior students in every event (Table 3 ).

\section{TABLE 1: EMS STUDENTS KNOWLEDGE OF COVID-19}

\begin{tabular}{|c|c|c|c|}
\hline No. & Items & Mean & SD \\
\hline 1 & $\begin{array}{l}\text { I participate in drills or exercises for COVID-19 preparedness at my workplace (clinic, } \\
\text { hospital, etc.) on a regular basis. }\end{array}$ & 2.85 & 1.41 \\
\hline 2 & I have participated in plan drafting and planning for COVID-19 situations in my community. & 2.51 & 1.58 \\
\hline 3 & I know who to contact (chain of command) in COVID-19 situations in my community. & 3.31 & 1.44 \\
\hline 4 & $\begin{array}{l}\text { I have a list of contacts in the medical or health community in which I practice. I know } \\
\text { referral contacts in case of a COVID-19 situation (health department, e.g.). }\end{array}$ & 2.9 & 1.48 \\
\hline 5 & $\begin{array}{l}\text { I participate in one of the following educational activities on a regular basis: continuing } \\
\text { education classes, seminars, or conferences related to COVID-19 preparedness. }\end{array}$ & 3.29 & 1.65 \\
\hline 6 & $\begin{array}{l}\text { I am aware of classes about COVID-19 preparedness that are offered at either my } \\
\text { workplace, the university, or community. }\end{array}$ & 3.12 & 1.65 \\
\hline 7 & $\begin{array}{l}\text { I would be interested in educational classes on COVID-19 preparedness that relate } \\
\text { specifically to my community situation. }\end{array}$ & 3.1 & 1.82 \\
\hline 8 & I find that the research literature on COVID-19 preparedness is easily accessible. & 2.62 & 1.41 \\
\hline 9 & I find that the research literature on COVID-19 preparedness is understandable. & 2.92 & 1.17 \\
\hline 10 & $\begin{array}{l}\text { Finding relevant information about COVID-19 preparedness related to my community } \\
\text { needs is an obstacle to my level of preparedness }\end{array}$ & 3.15 & 1.44 \\
\hline
\end{tabular}


www.ijpsonline.com

I know where to find relevant research or information related to COVID-19 preparedness to fill in gaps in my knowledge.

In case of a COVID-19 situation I think that there is sufficient support from local officials on the county, region or governance level.

I am aware of what the potential risks in my community are (e.g. virus, bacterial, pathogenic, etc).

I know the limits of my knowledge, skills and authority as an EMS student to act in COVID-19 situations and I would know when I exceed them.

I feel confident recognizing differences in health assessments indicating potential exposure to COVID-19.

\section{TABLE 2: EMS STUDENTS SKILLS OF COVID-19}

\begin{tabular}{|c|c|c|c|}
\hline No & Items & Mean & SD \\
\hline 1 & I believe that I am prepared for managing COVID- 19. & 3.39 & 1.22 \\
\hline 2 & $\begin{array}{l}\text { I participate/have participated in creating new guidelines, plans, or lobbying for } \\
\text { improvements on the local or national level in COVID-19. }\end{array}$ & 2.42 & 1.35 \\
\hline 3 & I would be considered a key leadership figure in my community in a COVID-19 situation. & 3.41 & 1.58 \\
\hline 4 & $\begin{array}{l}\text { I know how to use personal protective equipment, in case of a viral, bacterial or } \\
\text { pathogenic, }\end{array}$ & 2.86 & 1.67 \\
\hline 5 & $\begin{array}{l}\text { I know how to execute decontamination procedures, in case of a viral, bacterial or } \\
\text { pathogenic, }\end{array}$ & 2.54 & 1.73 \\
\hline 6 & $\begin{array}{l}\text { I know how to perform isolation procedures, so in a case of viral, bacterial or pathogenic I } \\
\text { minimize the risks of community exposure. }\end{array}$ & 2.73 & 1.53 \\
\hline 7 & I am familiar with the local emergency response system for COVID-19. & 2.94 & 1.06 \\
\hline 8 & I am familiar with accepted triage principles used in COVID-19 situations & 3.88 & 1.45 \\
\hline 9 & I have personal/family emergency plans in place for COVID-19 situations. & 2.99 & 1.66 \\
\hline 10 & $\begin{array}{l}\text { I have an agreement with loved ones and family members on how to execute our personal/ } \\
\text { family COVID-19 related plans. }\end{array}$ & 2.94 & 1.74 \\
\hline 11 & $\begin{array}{l}\text { I am able to describe my role in the response phase of COVID-19 in the context of my } \\
\text { workplace, the general public, media and personal contacts. }\end{array}$ & 3.23 & 1.61 \\
\hline 12 & I am familiar with the main COVID-19 signs and symptoms and effective treatments. & 2.5 & 1.53 \\
\hline 13 & $\begin{array}{l}\text { As an EMS student, I would feel confident in my abilities as a health care provider and first } \\
\text { responder in COVID-19 situation. }\end{array}$ & 3.36 & 1.66 \\
\hline 14 & $\begin{array}{l}\text { As an EMS student, I would feel confident as a manager or coordinator of a COVID-19 } \\
\text { isolation accommodation. }\end{array}$ & 3.52 & 1.73 \\
\hline 15 & $\begin{array}{l}\text { As an EMS student, I would feel reasonably confident in my abilities to be a member of a } \\
\text { decontamination team. }\end{array}$ & 3.55 & 1.52 \\
\hline 16 & In case of a COVID-19, I know how to perform focused health history and assessment. & 2.97 & 1.55 \\
\hline 17 & $\begin{array}{l}\text { I feel reasonably confident I can care for patients independently without supervision of a } \\
\text { physician in a COVID-19 situation. }\end{array}$ & 3.28 & 1.74 \\
\hline 18 & $\begin{array}{l}\text { I am familiar with the organizational logistics and roles among local and national agencies } \\
\text { in COVID-19 response situations. }\end{array}$ & 2.73 & 1.53 \\
\hline 19 & $\begin{array}{l}\text { I would feel confident implementing plans, evacuation procedures and similar functions } \\
\text { regarding COVID-19. }\end{array}$ & 2.97 & 1.75 \\
\hline 20 & I would feel confident in providing health education related to COVID-19 issues & 3.84 & 1.63 \\
\hline
\end{tabular}




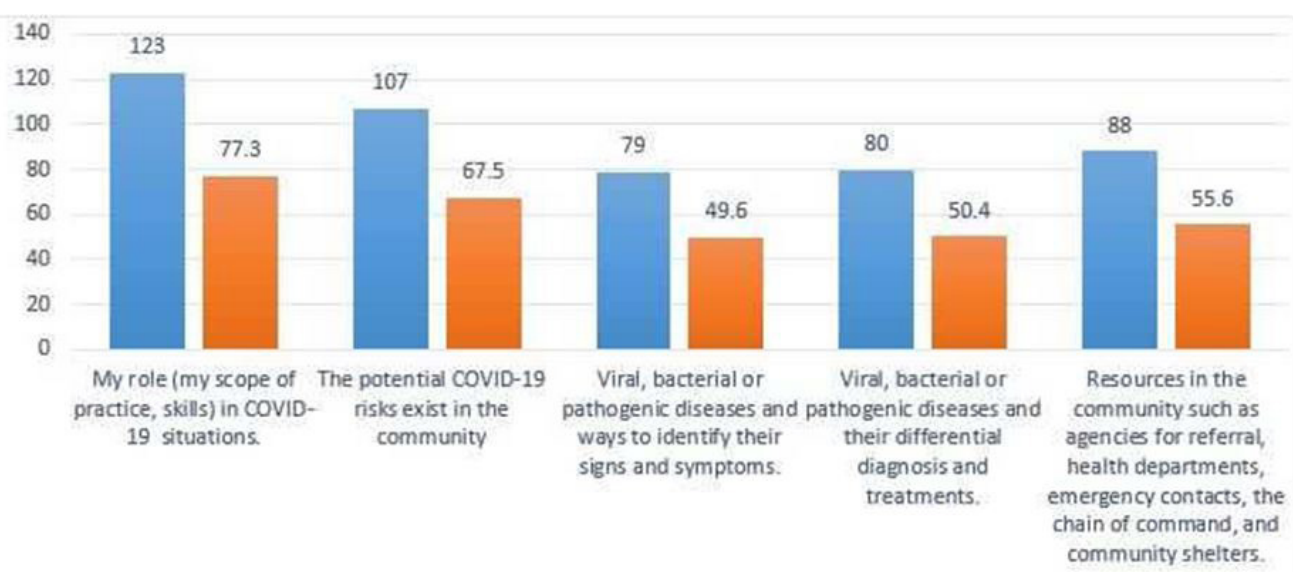

Fig. 1: Areas of enhancement in EMS program education for COVID-19 preparedness

TABLE 3: MANN-WHITNEY TEST COMPARISONS OF STUDENTS KNOWLEDGE AND SKILLS SCALE SCORE DISTRIBUTION FOR YEAR OF STUDY

\begin{tabular}{ccccccc}
\hline \multirow{2}{*}{ Year of study } & \multicolumn{3}{c}{ Total knowledge } & \multicolumn{3}{c}{ Total skills } \\
\cline { 2 - 7 } & $\mathrm{u}$ & $\mathbf{z}$ & $\mathrm{p}$ & $\mathrm{u}$ & $\mathrm{z}$ & $\mathrm{P}$ \\
\hline $3^{\text {rd }} \mathrm{y} \& 4^{\text {th }} \mathrm{y}$ & 65 & -7.238 & $<0.001^{*}$ & 53 & -7.340 & $<0.001^{*}$ \\
$3^{\text {rd }} \mathrm{y} \& 5^{\text {th }} \mathrm{y}$ & 62 & -7.213 & $<0.001^{*}$ & 55 & 7.499 & $<0.001^{*}$ \\
$4^{\text {th }} \mathrm{y} \& 5^{\text {th }} \mathrm{y}$ & 252.5 & -4.962 & $<0.001^{*}$ & 196.5 & -5.527 & $<0.001^{*}$ \\
\hline
\end{tabular}

Note: Significant at $p<0.001$

Considering the scientific reports shortage in the topic related to EMS student's preparedness for COVID-19, specifically in Saudi Arabia, this study investigated this area and assessed how they acquired knowledge and skills related to COVID-19 on the individual and group levels. A number of assumptions and questions emerged spontaneously from the main research aims regarding the perception of EMS students of their preparedness for COVID-19 during the EMS bachelor's degree program. This study adopted a descriptive cross-sectional survey research design, At this challenging time, we explored the status of EMS student's preparedness not only because of the global spread of COVID-19 and the rise in deaths from it but also because of the growing international concerns about the effects of COVID-19 on the provision of health and education, especially for EMS students.

The findings from EMS student's responses indicated a deficiency in knowledge and skills required to deliver optimum professional response to COVID-19. The EMS students had moderate to weak levels of COVID-19 preparedness in terms of knowledge and skills, which revealed inadequate capabilities that might hinder them from taking an effective action in COVID-19 related proceedings. However, the literature from outside Saudi Arabia ${ }^{[16]}$ has found that $89 \%$ of HCWs have sufficient knowledge about COVID-19 and Saqlain et al. ${ }^{[17]}$ have reported satisfactory knowledge (93.2 \%), attitude (mean 8.43) and practice (88.7\%) regarding COVID-19 among HCWs. However, the two scientific studies have involved HCWs, not health students specifically EMS students. Nonetheless, they have reported less understanding of EMS paramedic of $36.72 \pm 4.82$ and $90.5 \%$ respectively than physicians, pharmacists and nurses. The findings confirmed the recent results reported by Alrazeeni ${ }^{[18]}$ that only 4.2 $\%$ of EMS students have adequate information on the transmission, diagnosis and prevention of COVID-19.

As an indication of the maturity of the EMS students, a large percentage of them $(77 \%, n=123)$ believe that the curriculum of the EMS program should address topics concerning COVID-19 and preparing them for it. It is indeed a genuine reflection about their appreciation and sincere concerns about the magnitude of the EMS practice during the pandemic and the insignificance of their preparedness. Moreover, it is an indication that EMS students receive limited education in their EMS program regarding viral, bacterial or pathogenic diseases and the preparation to deal with them. 
EMS student's worries about their preparedness seem to be obviously stated in their responses. It imply the status of vulnerability that might result in developing symptomatic effects on student's mental health as after effects of the pandemic ${ }^{[20]}$ and emotional challenges EMS students encounter that have a negative effect on the quality of patient care and their professional and personal life ${ }^{[22]}$. This highlights the need of urging EMS educators and organizers to work more effectively to prepare their students to reduce these consequences. Pandemic preparedness of HCWs and EMS students should come before and during the pandemic ${ }^{[23,24]}$ and more importantly embedding competencies, logistical challenges, leadership skills, problem-based learning and preparedness exercises in the curriculum objectives, learning outcomes and learning domains ${ }^{[25]}$ was also suggested by the EMS students.

The findings showed the superiority of senior students, who completed the study plan and moved the internship practice $\left(5^{\text {th }} \mathrm{y}\right)$ in total knowledge and total skills, over junior students $\left(3^{\text {rd }} \mathrm{y}\right.$ and $\left.4^{\text {th }} \mathrm{y}\right)$ and that is in agreement with the literature ${ }^{[16,17]}$ as these students are about to become practitioners with a satisfactory level of skills and knowledge as reflected by the higher mean counts. The findings imply that the longer the students are exposed to education and practice in EMS, the better the status of knowledge and skills they have. Furthermore, this confirms the demand of overall students sought for embedding pandemic preparedness competencies in the curriculum of undergraduate EMS program. Competencies throughout logistical challenges, leadership skills, problem-based learning and preparedness exercises in the curriculum objectives, learning outcomes and learning domains were suggested by Greenberg et al. ${ }^{[25]}$.

The occurrence and spread of epidemics and pandemics can be inevitable. Therefore, reducing their severe effects is compulsory. Among the first people to be exposed to infection and the effects of infectious diseases are front line HCWs like EMS students. Preparing EMS students well to respond to any pandemic, such as COVID-19, is vital. The results of this study showed that EMS students presented moderately inadequate knowledge and skills related to COVID-19. Moreover, a level of uncertainty about their ability to respond adequately or contribute satisfactorily in the pandemic related events, EMS students suggested in their feedback expressed the need to more embedding of knowledge and skills of COVID-19 in the EMS program curriculum.

\section{Strength and limitations:}

This study is the first on this topic in Saudi Arabia and stimulates the emergence of more research to examine the findings presented. Since this study was applied in a public college, the reader might look forward to the perception from EMS students in private colleges. Preparing EMS students requires studies and applied experiences to improve their skills and knowledge. In designing EMS programs, importance is given to topics related to student's preparedness to face pandemics. This includes courses dealing with microorganisms, including bacteria, viruses and fungi, for students to learn from.

\section{Acknowledgments:}

This work was supported by Prince Sultan Bin AbdulAziz College for Emergency Medical Services Research Center, Deanship of Scientific Research, King Saud University, Riyadh, Saudi Arabia.

\section{Author statement:}

All authors contributed to data analysis, drafting or revising the article, gave final approval of the version to be published, agreed to the submitted journal and agree to be accountable for all aspects of the work.

\section{REFERENCES}

1. Zhu N, Zhang D, Wang W, Li X, Yang B, Song J, et al. A novel coronavirus from patients with pneumonia in China, 2019. N Engl J Med 2020;382(8):727-33.

2. Li Q, Guan X, Wu P, Wang X, Zhou L, Tong Y, et al. Early transmission dynamics in Wuhan, China, of novel coronavirusinfected pneumonia. N Engl J Med 2020;382(13):1199-207.

3. Lu H, Stratton CW, Tang YW. Outbreak of pneumonia of unknown etiology in Wuhan, China: The mystery and the miracle. J Med Virol 2020;92(4):401-2.

4. Zhang M, Zhou M, Tang F, Wang Y, Nie H, Zhang L, et al. Knowledge, attitude and practice regarding COVID-19 among healthcare workers in Henan, China. J Hosp Infect 2020;105(2):183-7.

5. Yang BY, Barnard LM, Emert JM, Drucker C, Schwarcz L, Counts CR, et al. Clinical characteristics of patients with coronavirus disease 2019 (COVID-19) receiving emergency medical services in King County, Washington. JAMA Netw Open 2020;3(7):e2014549.

6. Coronavirus (COVID-19) vaccinations data. Statistics and Research; 2021.

7. Shi H, Han X, Jiang N, Cao Y, Alwalid O, Gu J, et al. Radiological findings from 81 patients with COVID-19 pneumonia in Wuhan, China: a descriptive study. Lancet Infect Dis 2020;20(4):425-34.

8. Tian S, Hu N, Lou J, Chen K, Kang X, Xiang Z, et al. Characteristics of COVID-19 infection in Beijing. J Infect 2020;80(4):401-6. 
9. Sahin AR, Erdogan A, Agaoglu PM, Dineri Y, Cakirci AY, Senel ME, et al. 2019 novel coronavirus (COVID-19) outbreak: a review of the current literature. Eur J Med Oncol 2020;4(1):1-7.

10. Wang L, Wang Y, Ye D, Liu Q. Review of the 2019 novel coronavirus (SARS-CoV-2) based on current evidence. Int $\mathrm{J}$ Antimicrob Agents 2020;55(6):105948.

11. COVID-19 coronavirus pandemic. Current total number of coronavirus cases, deaths and recovery Worldwide. Worldometer; 2021.

12. WHO Coronavirus (COVID-19) Dashboard. World Health Organization; 2021.

13. Pladson K. The COVID-19 vaccines: Where do they come from? Where will they go? 2021.

14. Buick JE, Cheskes S, Feldman M, Verbeek PR, Hillier M, Leong YC, et al. COVID-19: What paramedics need to know! CJEM 2020;22(4):426-30.

15. Fernandez R, Lord H, Halcomb E, Moxham L, Middleton R, Alananzeh I, et al. Implications for COVID-19: a systematic review of nurses' experiences of working in acute care hospital settings during a respiratory pandemic. Int $\mathrm{J}$ Nurs Stud 2020;111:103637.

16. Zhong BL, Luo W, Li HM, Zhang QQ, Liu XG, Li WT, et al. Knowledge, attitudes, and practices towards COVID-19 among Chinese residents during the rapid rise period of the COVID-19 outbreak: a quick online cross-sectional survey. Int J Biol Sci 2020;16(10):1745.

17. Saqlain M, Munir MM, Rehman SU, Gulzar A, Naz S, Ahmed $\mathrm{Z}$, et al. Knowledge, attitude, practice and perceived barriers among healthcare workers regarding COVID-19: a crosssectional survey from Pakistan. J Hosp Infect 2020;105(3):41923.
18. Alrazeeni D. Knowledge, attitude, and practice toward COVID-19 among paramedics in Saudi Arabia: Implications for educational program. Int J Adv Appl Sci 2021;8(3):71-7.

19. Ferrel MN, Ryan JJ. The impact of COVID-19 on medical education. Cureus 2020;12(3): e7492.

20. Alsafi Z, Abbas AR, Hassan A, Ali MA. The coronavirus (COVID-19) pandemic: adaptations in medical education. Int J Surg 2020;78:64-5.

21. Del Rio C, Malani PN. 2019 novel coronavirus-important information for clinicians. JAMA 2020;323(11):1039-40.

22. Alrazeeni D, Al Sufi MS, Parakkal S, Shaikh S, Shams H. Emotional challenges of paramedical students during clinical practice and their Coping strategies in Saudi Arabia. Biosci Res 2020;17(4):2646-53.

23. Liang ZC, Ooi SB, Wang W. Pandemics and their impact on medical training: lessons from Singapore. Acad Med 2020;95(9):1359-61.

24. Perkins A, Kelly S, Dumbleton H, Whitfield S. Pandemic pupils: COVID-19 and the impact on student paramedics. Aus J Paramed 2020;17:1-4.

25. Greenberg N, Docherty M, Gnanapragasam S, Wessely S. Managing mental health challenges faced by healthcare workers during covid-19 pandemic. BMJ 2020;368:m1211.

26. Alrazeeni D. Public anxiety during Coronavirus-19 disease (COVID-19) in Saudi Arabia: Indication for a psychological assistance intervention. Int J Adv Appl Sci 2021:12-6.

27. Al Khalaileh MA, Bond E, Alasad JA. Jordanian nurses' perceptions of their preparedness for disaster management. Int Emerg Nurs 2012;20(1):14-23.

This is an open access article distributed under the terms of the Creative Commons Attribution-NonCommercial-ShareAlike 3.0 License, which allows others to remix, tweak, and build upon the work non-commercially, as long as the author is credited and the new creations are licensed under the identical terms

This article was originally published in a special issue,
"Diagnostic and Therapeutic Advances in Biomedical Research
and Pharmaceutical Sciences"
Indian J Pharm Sci $2021: 83(5)$ spl issue "177-184"

